\title{
Improving the Performance of Drilling Fluid Using MgO Nano Particles
}

\author{
Ghufran Falih", Asawer A. Alwasiti ${ }^{*}$ Nada S. Alzubaidi** \\ *Department of Petroleum Technology, University of Technology, Baghdad-Iraq \\ ** Department of Petroleum Engineering, College of Engineer, University of Baghdad, \\ Baghdad-Iraq
}

\section{$\underline{\text { Abstract }}$}

One of the most important factors that cause formation damage is drilling fluid invasion caused by mud filtration. Hence, it is essential to minimize the mud filtration in order to reduce its damage to the formation using drilling fluid additives that control and minimize the filtration rate. Magnesium Oxide $(\mathrm{MgO})$ nanoparticles at different masses $(0.01,0.05,0.07,0.1$, and 0.2$)$ gm with water base mud have been investigated in this research to measure its effect on the filtration rate. Four types of drilling fluid are used in this research; API water base mud WBM, Saturated salt water mud, DURA THERM mud and polymer mud. Filtration rate was tested under high temperature high pressure (HTHP) conditions; at (75 and 100) $\mathrm{C}$ and (500 psi), and at room temperature and pressure at (100 psi). The viscosity of all drilling fluid types is measured using a rotational viscometer at room temperature and atmospheric pressure. In general, the results showed that adding $\mathrm{MgO}$ nano particle helped in reducing the filtration rate of drilling fluid, the best results were gained in DURA THERM mud and Saturated Salt Water Mud at $\mathrm{MgO}$ concentrationof $0.07 \mathrm{gm}$ and $0.2 \mathrm{gm}$, respectively; where the filtrate reduction $60 \%$ at 100 C. Also, $\mathrm{MgO}$ addition improves rheological properties and drilling fluid stability Key words: Nanoparticales, drilling fluid, fluid loss control, HTHP conditions

$$
\text { تحسين اداء سائل الحفر باستخدام دقائق اوكسيد المغتيسيوم النانوية }
$$

ان من اهم العو امل المسببه ضرر للطبقات المكمنية هو اختراق سائل الحفر لها وذلك ناجم عن ترشيح الطين. لذلك كان من الضروري التقليل من كمبة الر اشح للحد من الضرر للطبقات وذللك باستخدام اضافات لسائل الحفر للسبطره

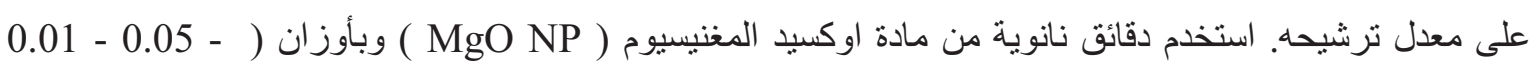
0.2 - 0.1 - 0.07) غرام مع الطين ذو الاساس المائي لغرض دراسة تاثثيره على معدل الترشيح. واستخدمت في منس

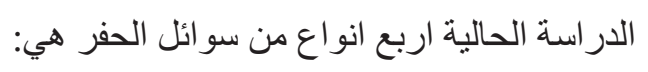


- API water base mud WBM

- Saturated salt water mud

- DURA THERM mud

- Polymer mud

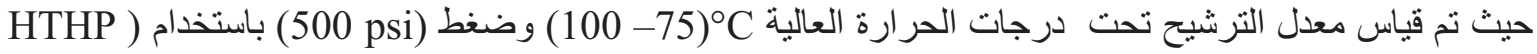
(filter press)، وبدرجة حرارة الغرفة وضغط (Filter press) بينما تم قياس الخواص (100) باستخدام

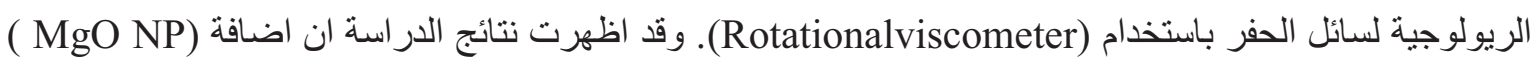
لسائل الحفر ساعد في اختز ال معدل الترشيح، و لاسيما عند اضافته (0.07) و (0.2) غم الى ( DURA THERM

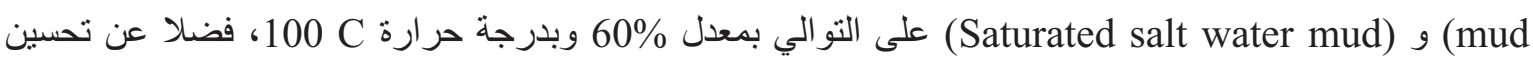
الخواص الريولوجية لسائل الحفر وزيادة استقراريته.

\section{Introduction}

Mud and filtration loss within the formation during drilling and completion operations, have direct effect on bore hole stability, the formation damage.Filtrate loss occurs in the high permeability formation where the drilling fluid filters through the wellbore and invades the formation. As a result of the mud filtration, the solid residue of the drilling fluid will form a layer of mud deposition which called cake on borehole wall. In high permeability formation, high pressure difference between the wellbore and the formation, and thick mud cake caused by high filtration rate can cause the drill pipe sticking.

Drilling operation considered as HTHP if bore hole static temperature and the pressure exceeds $\left(350^{\circ} \mathrm{F}, 25.000 \mathrm{psi}\right)$. However, as the depth of the drilling wells keeps increasing, more severe drilling conditions can be expected, which may exceed $600^{\circ} \mathrm{F}$ temperature and 40,000 psi pressure [1]. Most organic filtration control additives degradation begins when temperatures exceed $100 \mathrm{C}$, so it is very important to find other alternatives that can be used in HTHP conditions. Formation damage is related more to the type of filtrate than to theamount of filtrate lost to a formation. If the filtrate reacts with the formation solids or formation fluids, that cause a reduction in permeability [2].

The nanoparticle additives are explored as an alternative to the polymer based additives. Inorganic characteristics of the nanoparticles additives are expected to stabilize the drilling fluids even at high temperature and high pressure conditions. [1] Used three types of nanoparticales (Nickle, copper and Cobalt) to replace polymer additives in drilling fluids. They found that these additives lose their effectiveness at high temperatures and when 
small amount of these materials had been used, the mud exhibited not only excellent shearthinning behavior but also stable rheological properties at high temperature.Jimet al.used two types of mud (water base mud and salt mud) with two types of nano additives (Graphene oxide and carbon nano tube), they gained a good result on rheological properties but the fluid loss control still an issue with these fluids [3]. Abdul Razak et al.used Multi Walled Carbon Nano Tubes (MWCNT) to improve the rheological properties of two mud types (water base mud and ester base mud), they showed good results on rheological and filtration properties with increasing MWCVT particle mass in ester base mud, they also concluded that increasing temperature affected on rheological, filteration and stability properties of both mud types [4].

Norazwan et al tended to improve the performance of SBM with silicon dioxide nano powder with two steps, first by measuring rheological and filtration properties for base fluid at different concentrations of nano silica and temperatures $(275 \& 350)^{\circ} \mathrm{C}$, second, by leavingsamples in hot rolling for $16 \mathrm{hr}$. They found that nano silica proven to be a good fluid loss control with stablerheology [5]. Matthew M. et al. studied the effect of $\mathrm{Fe}_{2} \mathrm{O}_{3}$ nano particles, as fluid loss control additives, at different concentrations with two other additives; Iron oxide Clay Hybrid (ICH) and AluminoSilica Clay Hybrid (ASCH). The result showed a good reduction in filtration volume up to $37 \%$ and $47 \%$ at normal condition and at HTHP respectively [6]. Zisis. et al. tested two nano additives $\left(\mathrm{Fe}_{2} \mathrm{O}_{3}\right.$ and $\mathrm{SiO}_{2}$ ) in water base mud, they found that the reduction of filtration efficiency increased with increasing $\mathrm{Fe}_{2} \mathrm{O}_{3}$ concentration while silica nano powder was unstable under different temperatures [7].

The objective of this research is to investigate the influence of $\mathrm{MgO}$ nano particle at different concentrations on filtrate volume at HTHP conditions. Four types of drilling fluid have been used WBM, Dura THERM mud, saturated salt water mud and polymer mud.

\section{Experimental work}

\subsection{Materials}

$\mathrm{MgO}$ NP was equipped from Sky Spring Nano materials; it has size $20 \mathrm{~nm}$ with 99\% purity. Bentonite clay and other mud materials were supplied from Iraqi drilling company. The copolymers (TS30LC AND TS705) were equipped from SNF FLOERGER. 


\subsection{Experiments}

This study will focus on specific conditions, where at the large depths temperature degree and pressureincreases, certainly when drilling fluid passage through these conditions the mud properties would effect, especially filtration and rheological propertiesTherefore, this research include four types of water base drilling fluids (API WBM, DURA THERM mud, Saturated Salt Water mud and polymer mud), studying their behavior during three temperature degrees (room temperature, $75^{\circ} \mathrm{C}$ and $100{ }^{\circ} \mathrm{C}$ ) and then add $\mathrm{MgO} \mathrm{NP}$ at different weights $(0.01,0.05,0.07,0.1$ and 0.2$)$ gm to study its effect on the improvement mud properties (Rheological and filtration properties).

API WBM (22.5 gm) Bentonite and $(350 \mathrm{ml})$ water. Polymer mud (11.5 gm) Bentonite, $(350 \mathrm{ml})$ water, $(0.5 \mathrm{gm}) \mathrm{KOH}$, $(2 \mathrm{gm}) \mathrm{KCL}$, $(2 \mathrm{gm}) \mathrm{PAC}$ polymer and $(0.07$ gm) TS30LC copolymer, DURA THERM mudand Saturated Salt Water mud components are shown in Tables $(1,2)$.

Table (1) DURA THERM mud contents (MI manual)

\begin{tabular}{|c|c|c|}
\hline Materials & Weights $\mathbf{( g m )}$ & Primary function \\
\hline Bentonite & $1-10$ & Viscosity/Gel Strength / Filter Cake and Fluid Loss Control \\
\hline Barite & $0-600$ & Increase Density \\
\hline $\mathrm{NaOH}$ & $0.5-1.5$ & Increase $\mathrm{pH}$ \\
\hline $\mathrm{Ca}(\mathrm{OH})_{2}$ & $0-2$ & Treat out $\mathrm{CO}_{3}$ and $\mathrm{pH}$ \\
\hline Lignite & $15-20$ & Thinner and Fluid Loss Control \\
\hline $\mathrm{XG}$ polymer & $0.5-1.5$ & Viscosity / Gel Strength \\
\hline Thermix & $0-12$ & HTHP Fluid Loss Control \\
\hline RESINEX & $0-6$ & HTHP Fluid Loss Control \\
\hline
\end{tabular}


Table (2) Saturated Salt Water mud contents (MI manual)

\begin{tabular}{|c|c|c|}
\hline Materials & Weight(gm) & Primary function \\
\hline Bentonite & $10-30$ & Viscosity/Gel Strength / Filter Cake and Fluid \\
& & Loss Control \\
\hline Barite & $0-550$ & Increase Density \\
\hline $\mathrm{NaOH}$ & $0.2-2.5$ & Increase $\mathrm{pH}$ \\
\hline $\mathrm{NaCl}$ & $110-125$ & Increase Chloride \\
\hline $\mathrm{NaCO} 3$ & $0.2-1$ & Control Calcium \\
\hline $\mathrm{ChromLignosolfonate}$ & $5-15$ & Thinner and Fluid Loss Control \\
\hline PAC polymer & $0.5-2$ & Stability and Fluid Loss Control \\
\hline $\mathrm{XG}$ polymer & $0.25-1$ & Low Shear Rate Viscosity \\
\hline
\end{tabular}

Bentonite used as a base for the preparation of the drilling fluid. In this study, a specific amount of bentonite, related to each type mud, was added into $350 \mathrm{ml}$ of tap water. The drilling fluid was hydrated overnight, after nearly 16 hstirred by Hamilton beach mixer Figure 1(a) for 2 minutes, starts with adding mud components with continuous blending, the specific amount of nano add into the mud mixture and satire for 10 min with Hamilton beach mixer and 10 min with ultra sonic device Figure1 (b). Filtration properties at (100 psi pressure and room temperature) were obtained by using OFITE Filter Press Figure1 (d) and at $\left[(75,100){ }^{\circ}\right.$ Cand $(500$ psi) $]$ were obtained by using OFITE HTHP filter press Figure1 (e). The rheological properties were analyzed withOFITE model 900 Viscometer Figure1(c). Mud properties measured at drilling fluid laboratory at (University of Technology/ Petroleum Technology department). 


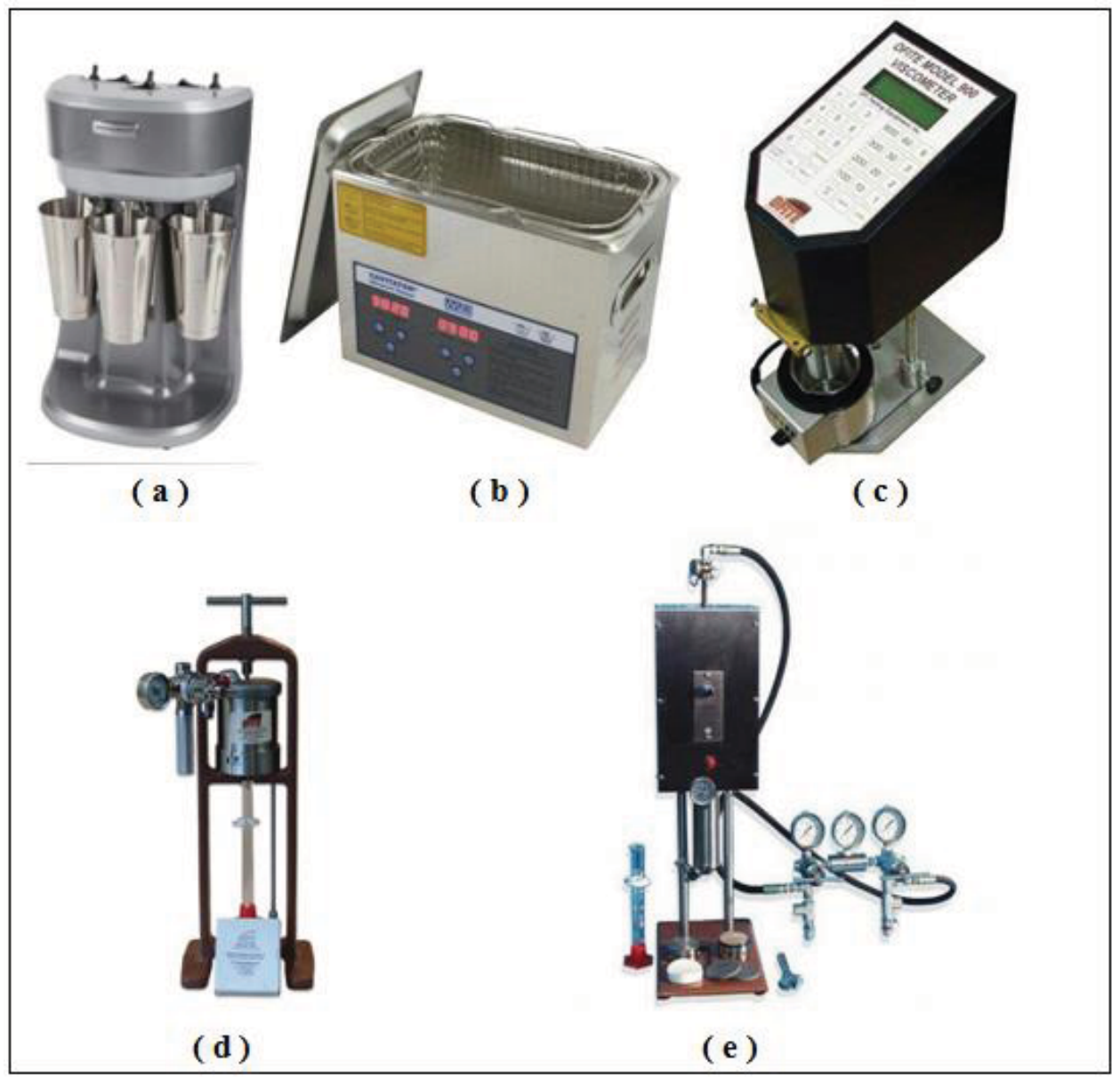

Fig. (1) Test devices (a) Hamilton Beach Mixer, (b) Ultra Sonic, (c) OFITE model 900 Viscometer, (d) OFITE Filter Press, (e) OFITE HTHP filter press

\section{Results and Discussion}

\section{3-1 Filtration Properties}

\section{3-1-1 Filtrate volume}

Figure (2) shows the effect of different temperature degrees with different $\mathrm{MgO} \mathrm{NP}$ weights on API WBM filtration rate. In general, it can be noticed that the filter loss increases as temperature increases, this mean that this material is losing its activity at highertemperature. On the other hand, at $35^{\circ} \mathrm{C}$ and $75^{\circ} \mathrm{C}$ filtrate volume is nearly stable with $\mathrm{MgO}$ addition while at $100^{\circ} \mathrm{C}$ the filtrate volume increased with $\mathrm{MgO}$ addition. This result differs from that obtained by the work of [8] who concluded that $\mathrm{MgO}$ addition improves filtration properties at room temperature, this due to the difference in bentonite type that has been used. 


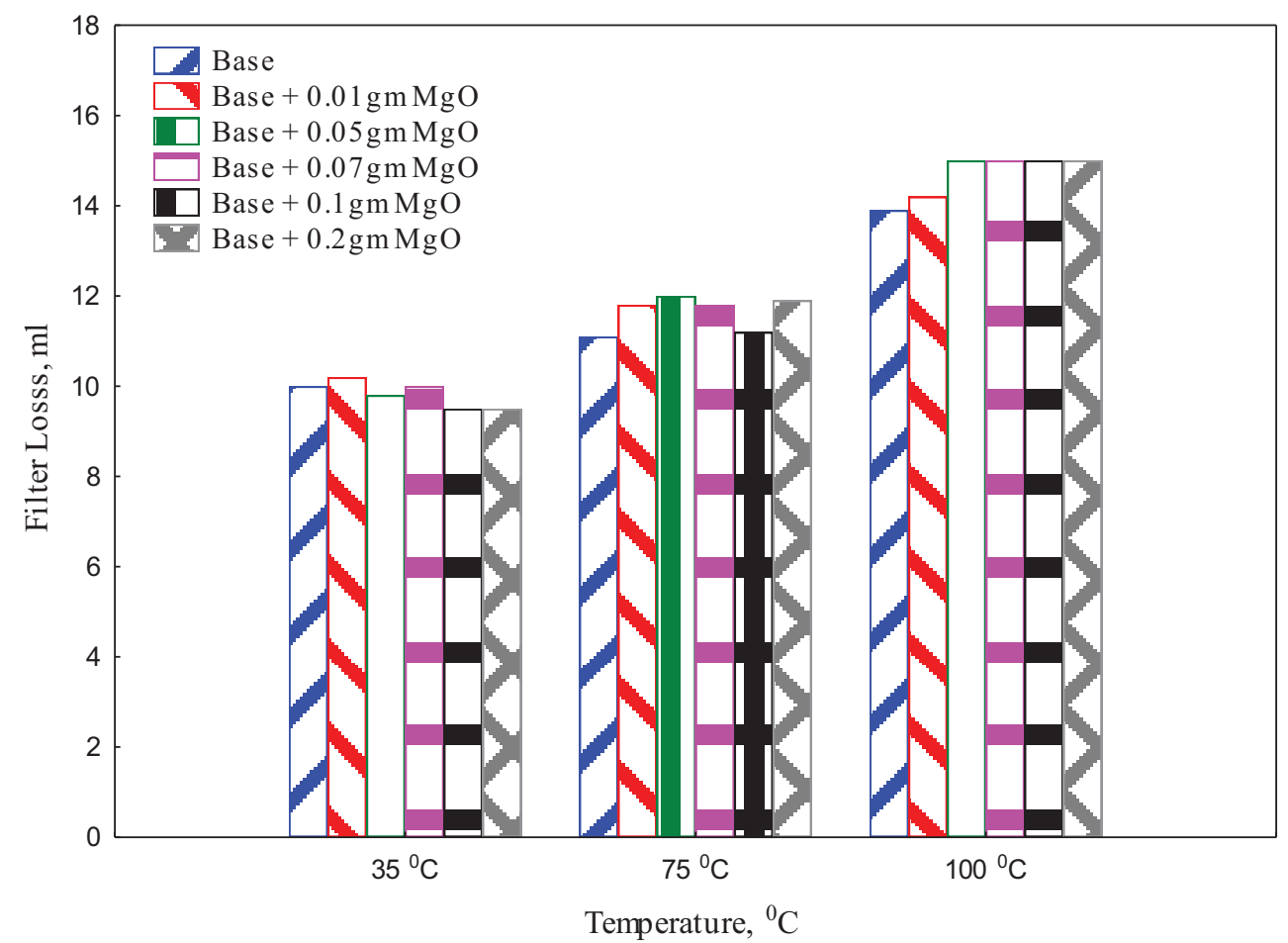

Fig. (2) Filter losses of API WBM with Mgo NP

Figure (3) shows the effect of different temperature degrees with different $\mathrm{MgO}$ weights on DURA THERM mud filtration rate, at $35^{\circ} \mathrm{C}$ the filtrate volume is slightly increased with $\mathrm{MgO} \mathrm{NP}$ weight until reached $0.2 \mathrm{gm} \mathrm{MgO}$ the filtration rate returns to the blank form. At higher temperature $(75$ and 100$){ }^{\circ} \mathrm{C}$, the filter losses have regular results with increasing nano particle weight. At $75^{\circ} \mathrm{C}$ the filtrate volume decreased about $30 \%$ after adding $0.01 \mathrm{gm} \mathrm{MgO} \mathrm{NP}$ but it increased with weight, while at $100^{\circ} \mathrm{C}$ the filtrate volume decreased with $\mathrm{MgO}$ NP concentration increasing and the best filtrate reduction ratio was $60 \%$ at $0.07 \mathrm{gm} \mathrm{MgO} \mathrm{NP}$ addition.

The effect of different MgO NP mass on Saturated Salt Water mud filtration rate at different temperatures is shown in Figure (4). The behavior of this mud type is un clear at small concentrations but after addition $0.07 \mathrm{gm}$ of $\mathrm{MgO} \mathrm{NP}$, the filter losses decreased and the filtrate reduction ratio was $42.8 \%, 46.4 \%, 60 \%$ at $35{ }^{\circ} \mathrm{C}, 75{ }^{\circ} \mathrm{C}$, and $100{ }^{\circ} \mathrm{C}$ respectively at $0.2 \mathrm{gm} \mathrm{MgO} \mathrm{NP}$ addition.

Figure (5) shows the effect of different temperature degrees with different $\mathrm{MgO}$ NP concentrations on Polymer mud filtration rate. The results show a uniform 
reduction in filtrate volume with increasing nano particle weight at $35^{\circ} \mathrm{C}$ till it reaches $21.6 \%$ at $0.2 \mathrm{gm} \mathrm{MgO}$ addition. The filtrate reduction decreased to $16 \%$ at $75^{\circ} \mathrm{C}$ with the addition of $0.1 \mathrm{gm}$ of $\mathrm{MgO} \mathrm{NP}$. At $100{ }^{\circ} \mathrm{C}$ the filtrate volume decreased with $\mathrm{MgO} \mathrm{NP}$ concentrations increasing and the maximum reduction in the filtrate was about $22.5 \%$ with adding $0.05 \mathrm{gm}$ of $\mathrm{MgO} \mathrm{NP}$.

Comparing this result with WBM results, it can be noticed that $\mathrm{MgO}$ addition affected on filter losses in DURA THERM, Saturated salt mud, and Polymer mud, especially at higher temperature, this can be due to the presence of another oxide like sodium hydroxide and potassium hydroxide as well as the presence of $\mathrm{Cl}$ ions, these ions can be replaced with $\mathrm{MgO}$ causing a deflocculating of the solution yielding a low permeability filter cake and reducing filter loss.

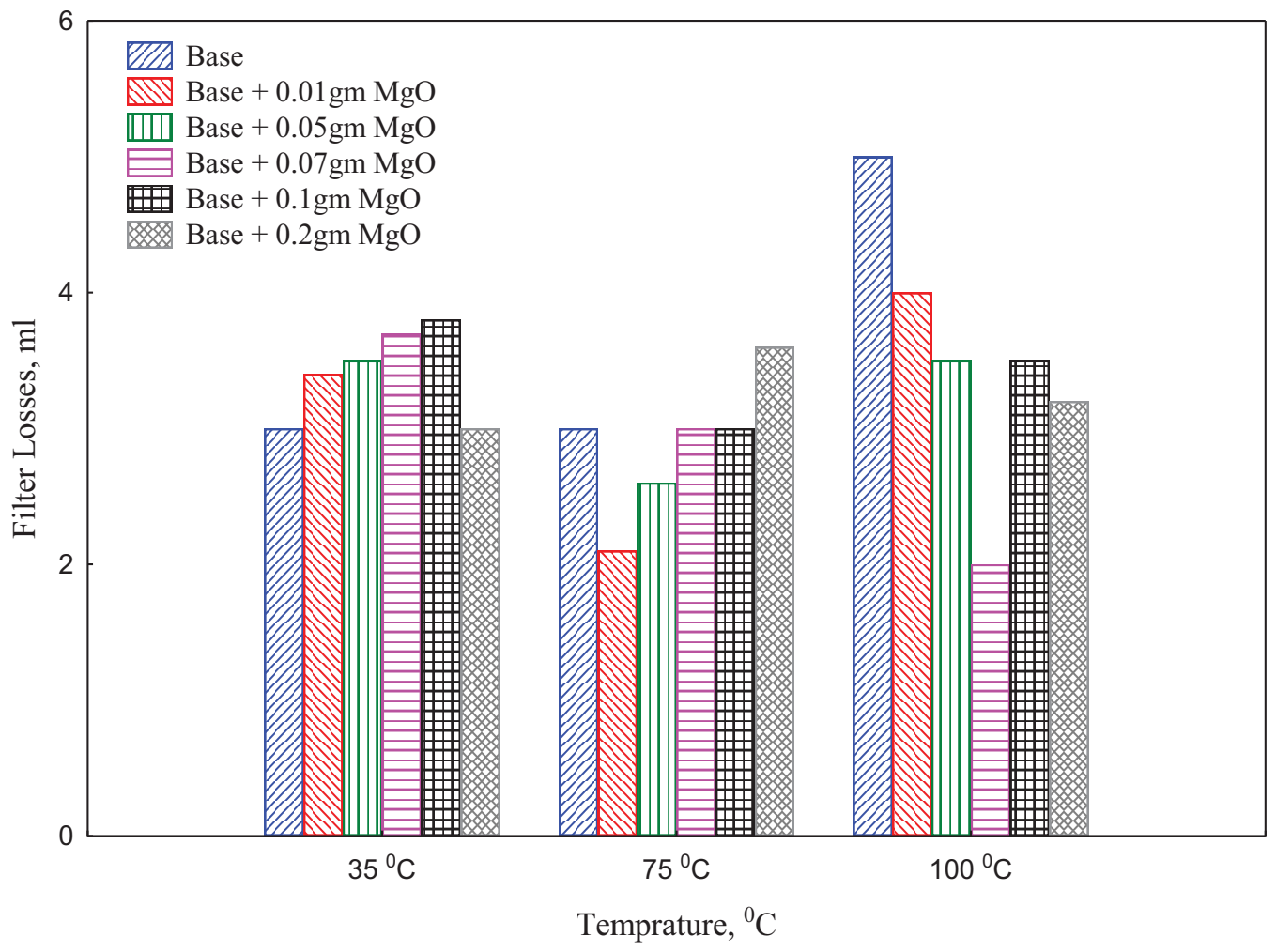

Fig. (3) Filter losses of DURA THERM mud with Mgo NP 


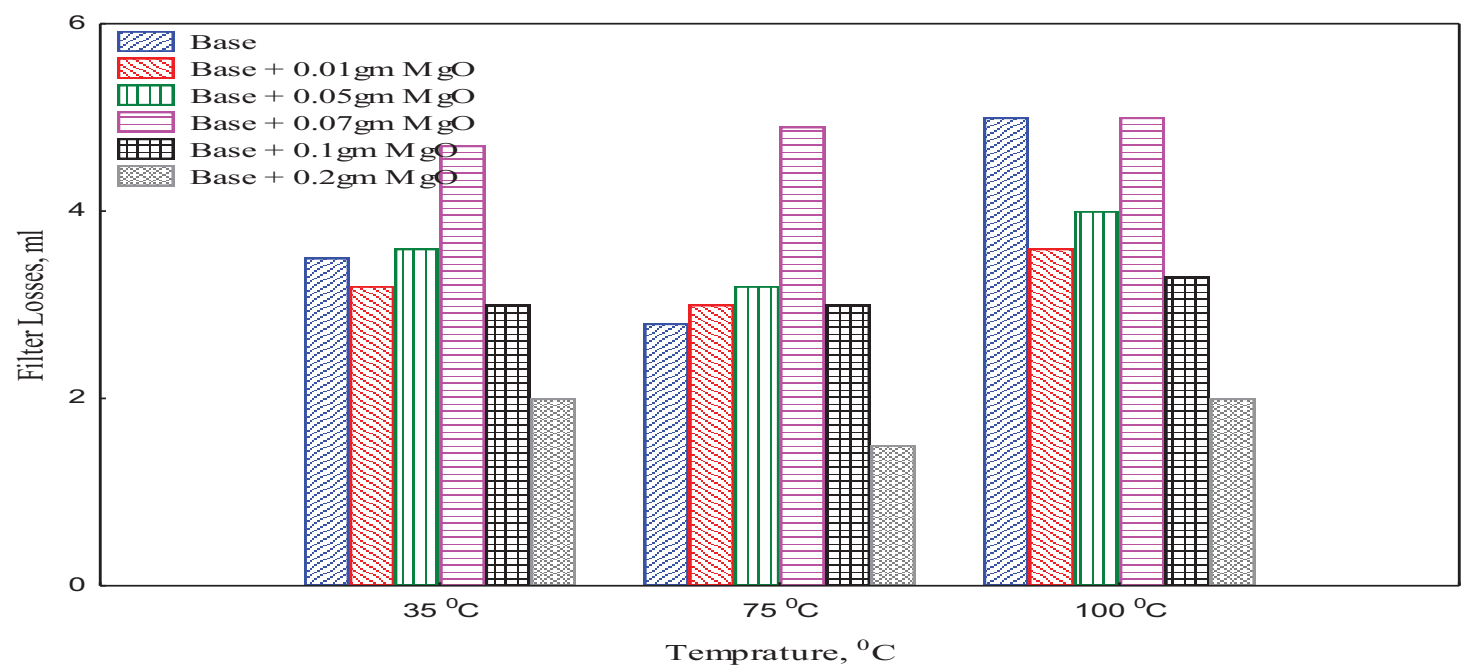

Fig. (4) Filter losses of Saturated Salt Water mud with Mgo NP

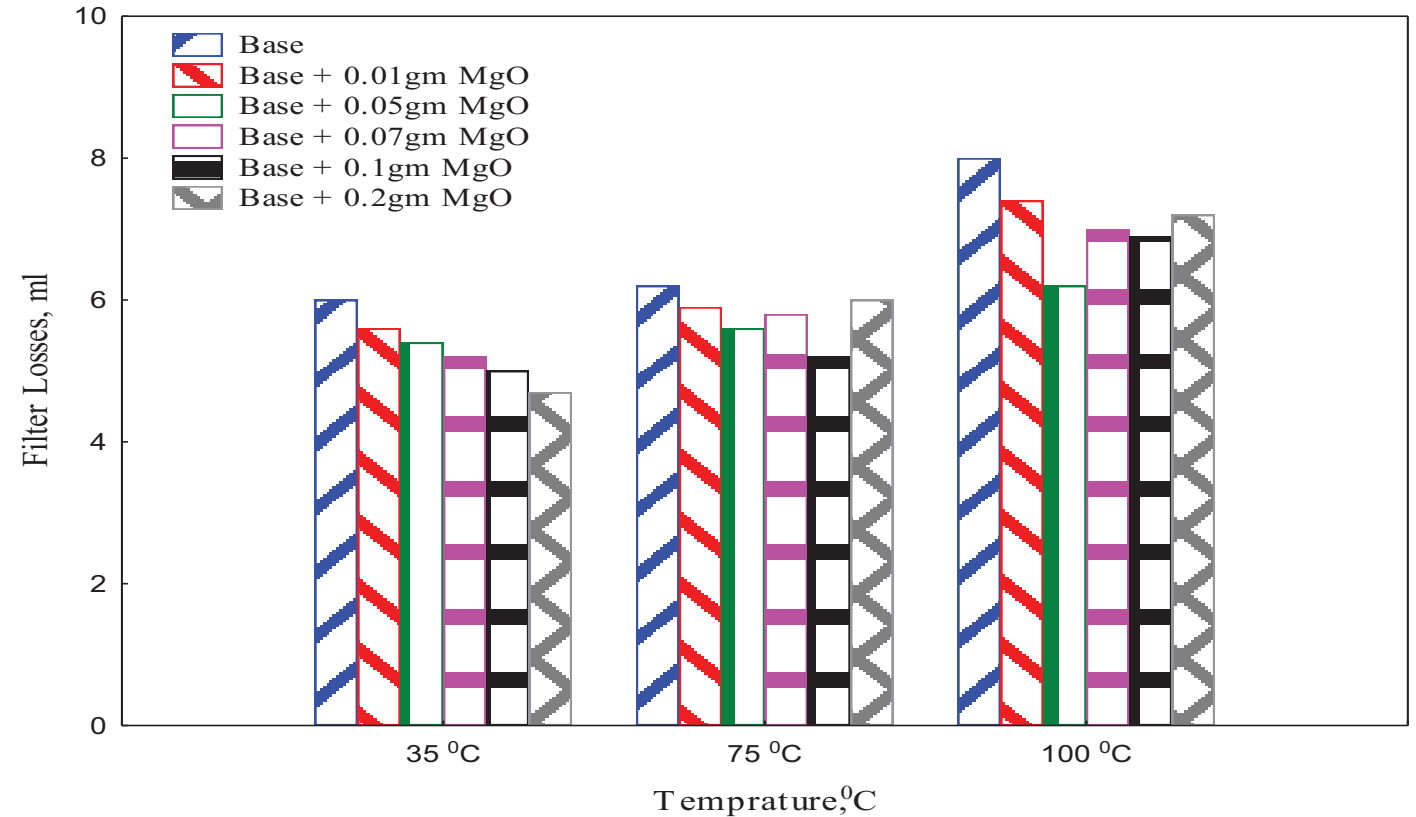

Figure (5) The filter losses of Polymer base mud

\section{3-1-2 Mud Cake Thickness}

The effect of MgO NP addition on Mud cake thickness of API WBM, DURA THERM mud, Saturated Salt Water mud and Polymer mud at different temperature degrees is shown in Figures (6-9) respectively. 
In API WBM and at $35^{\circ} \mathrm{C}$ and $75^{\circ} \mathrm{C}$ thickness of mud cake shows unstable behavior with $\mathrm{MgO}$ NP weights, while at $100^{\circ} \mathrm{C}$ mud thickness decreased about $13 \%$. Figures $(6$ and 7) indicates that at $35{ }^{\circ} \mathrm{C}$ the mud thickness, of DURA THERM mud, decreased about $44 \%$ with the addition of $0.1 \mathrm{gm} \mathrm{MgO}$, while at $75^{\circ} \mathrm{C}$ the mud thickness behaviors regular with $\mathrm{MgO} \mathrm{NP}$ addition and the minimum thickness was gained at $0.05 \mathrm{gm} \mathrm{MgO}$. At $100{ }^{\circ} \mathrm{C}$ the mud thickness decrease with MgO NP addition, in spite of decreasing in the loss, this may attribute to that $\mathrm{MgO}$ NP block the small channels in filter cake rather than building a new layer on the cake. The reduction ratio about $55.5 \%$ by $0.07 \mathrm{gm}$ of $\mathrm{MgO}$ NP.The same trend of behavior can be seen in Figures ( 8 and 9).

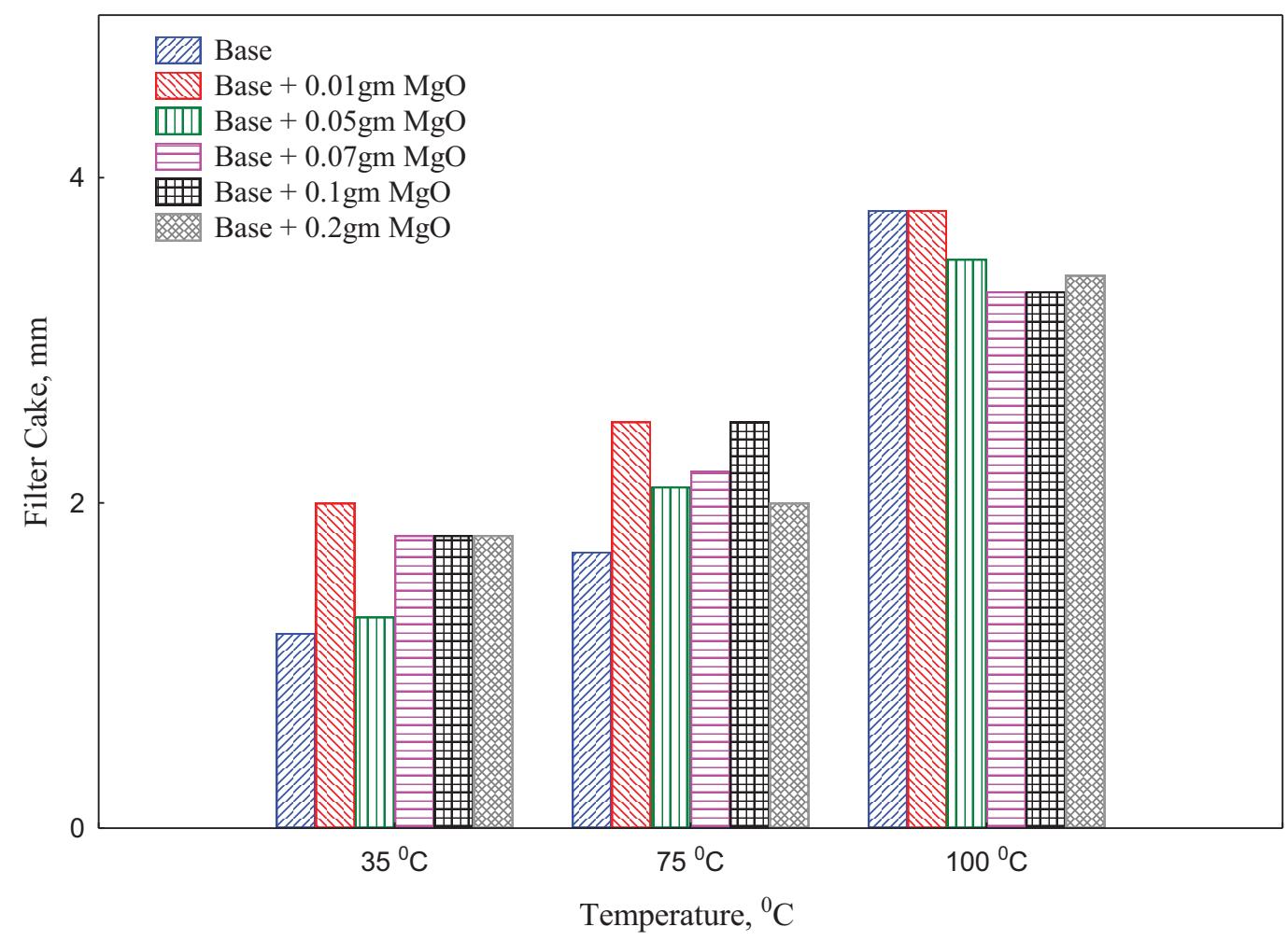

Fig. (6) Mud cake thickness of water base mud with $\mathrm{MgO}$ NP 


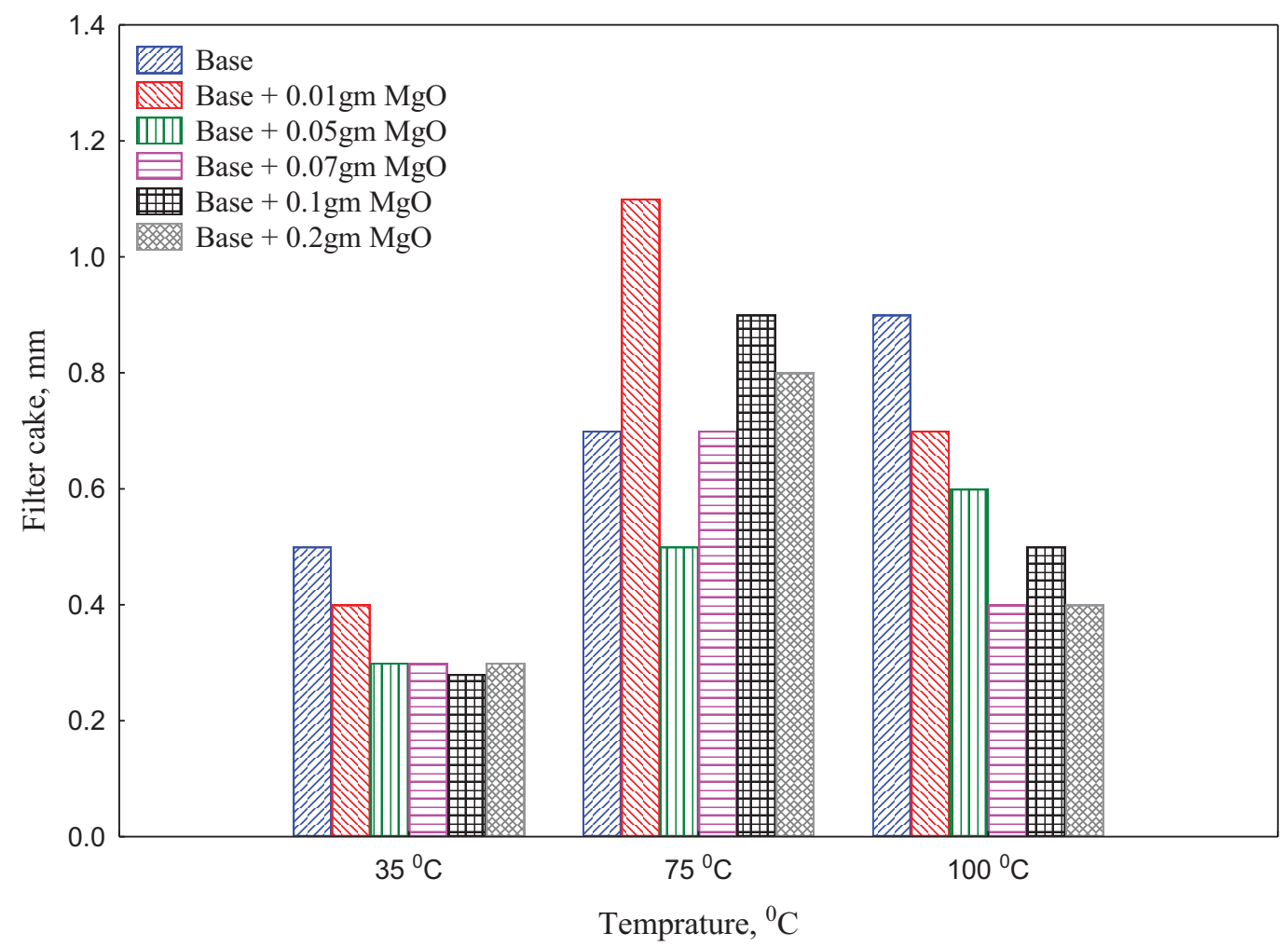

Fig. (7) Mud cake thickness of DURA THERM mud with MgO NP

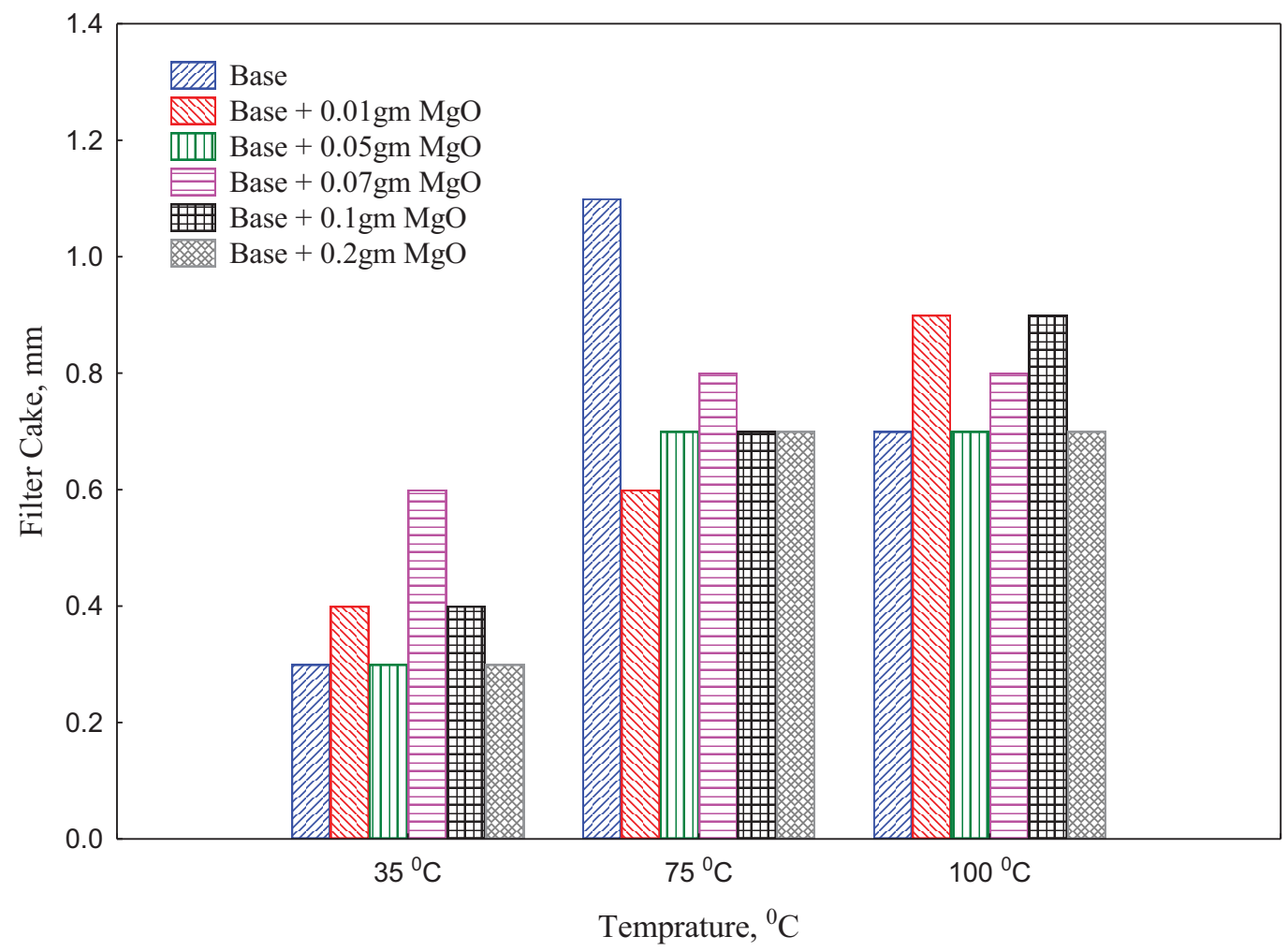

Fig. (8) Mud cake thicknessof Saturated Salt Water mud with MgO NP 


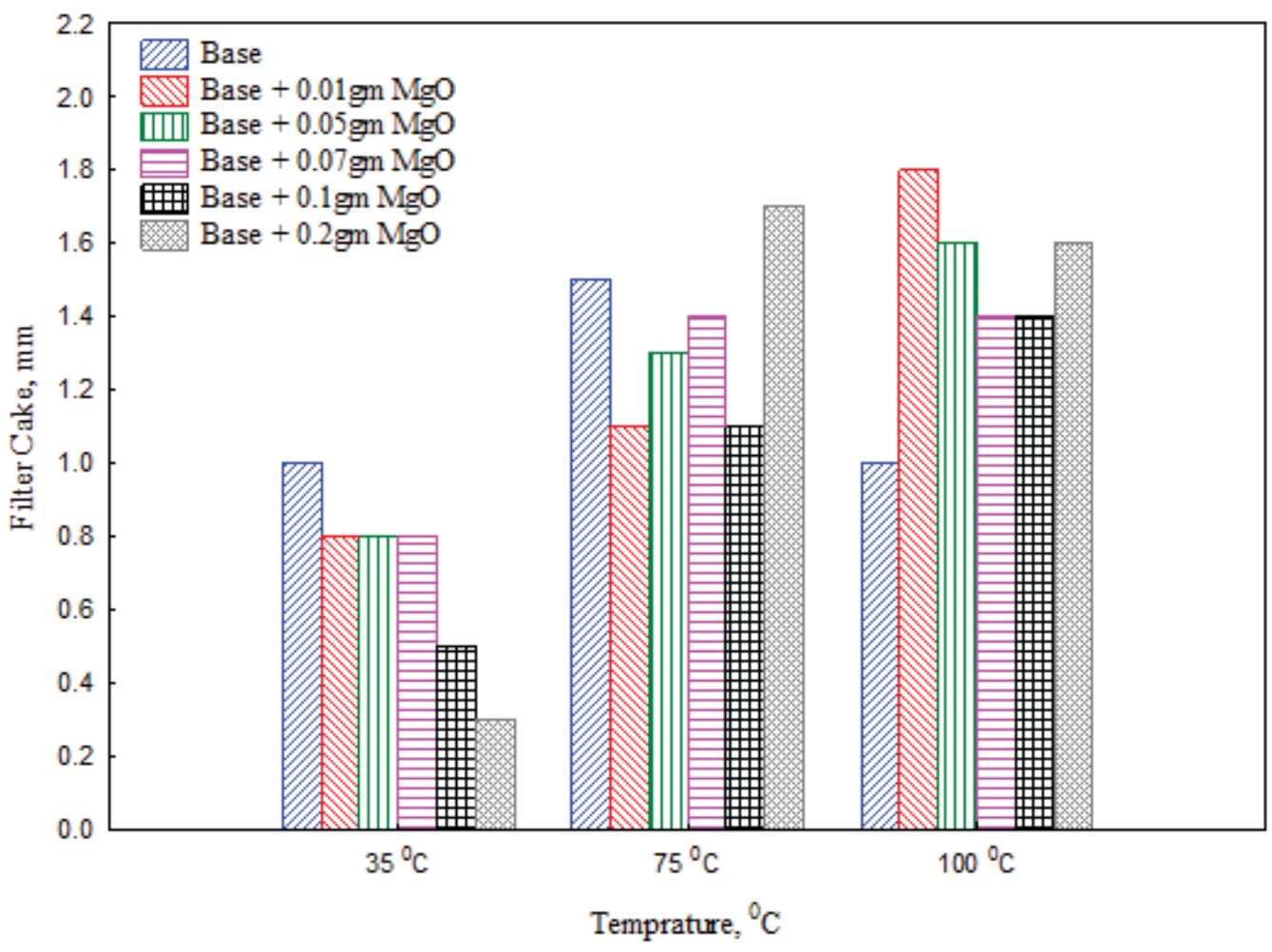

Fig. (9) Mud cake thicknessof Polymer mud with MgO NP

\section{3-2 Rheological Properties}

The effect of $\mathrm{MgO}$ NP on Rheological properties of four drilling fluid types is shown in Figures (10 and 11). Those figures show that adding MgO NP to water base mud led to increase in yield point value till it reaches $(65.5 \mathrm{lbf} / 100 \mathrm{ft} 2)$ at $0.2 \mathrm{gm}$ of $\mathrm{MgO} \mathrm{NP}$, while the plastic viscosity shows unstable behavior and it reaches $3.0 \mathrm{cP}$ when $0.2 \mathrm{gm}$ of $\mathrm{MgO}$ NP is added. In general, the high values of viscosity can be due to the higher attractive forces caused by adding $\mathrm{MgO} \mathrm{NP}$, where this causes moving the particles closer together so the attraction between particle is increased [9].

The effect of adding $0.01 \mathrm{gm}$ of MgO NP to DURA THERM mud is very clear, where the yield point and plastic viscosity increases to $53.6 \mathrm{lbf} / 100 \mathrm{ft} 2$ and $26.4 \mathrm{cP}$, respectively. Increasing the addition of $\mathrm{MgO} \mathrm{NP}$ more than that value causes a decrease in yield point and plastic viscosity till it reach to $24.9 \mathrm{lbf} / 100 \mathrm{ft} 2$ and $10.2 \mathrm{cP}$, respectively, at $0.2 \mathrm{gm} \mathrm{MgO} \mathrm{NP}$ addition. This is due to the presence of $\mathrm{NaOH}$ in DURA THERM mud which is reduced the magnesium by precipitation magnesium as $\mathrm{Mg}(\mathrm{OH})_{2}$.

Adding 0.1 gm of MgO NP to Saturated Salt Water mud causes an increase in 
plastic viscosity to $30.8 \mathrm{cP}$ while there is no significant changes in yield point values has been observed. More additions of $\mathrm{MgO}$ NP show unstable changes in yield point and plastic viscosity.

The effect of $\mathrm{MgO} \mathrm{NP}$ in polymer mud at low concentrations is clear, where adding $0.05 \mathrm{gm}$ of $\mathrm{MgO} \mathrm{NP}$ causes an increase in yield point to $103.6 \mathrm{lbf} / 100 \mathrm{ft} 2$ and 10.1 cp plastic viscosity. As the concentration of $\mathrm{MgO}$ NP increases a decrease in yield point and plastic viscosity is observed.

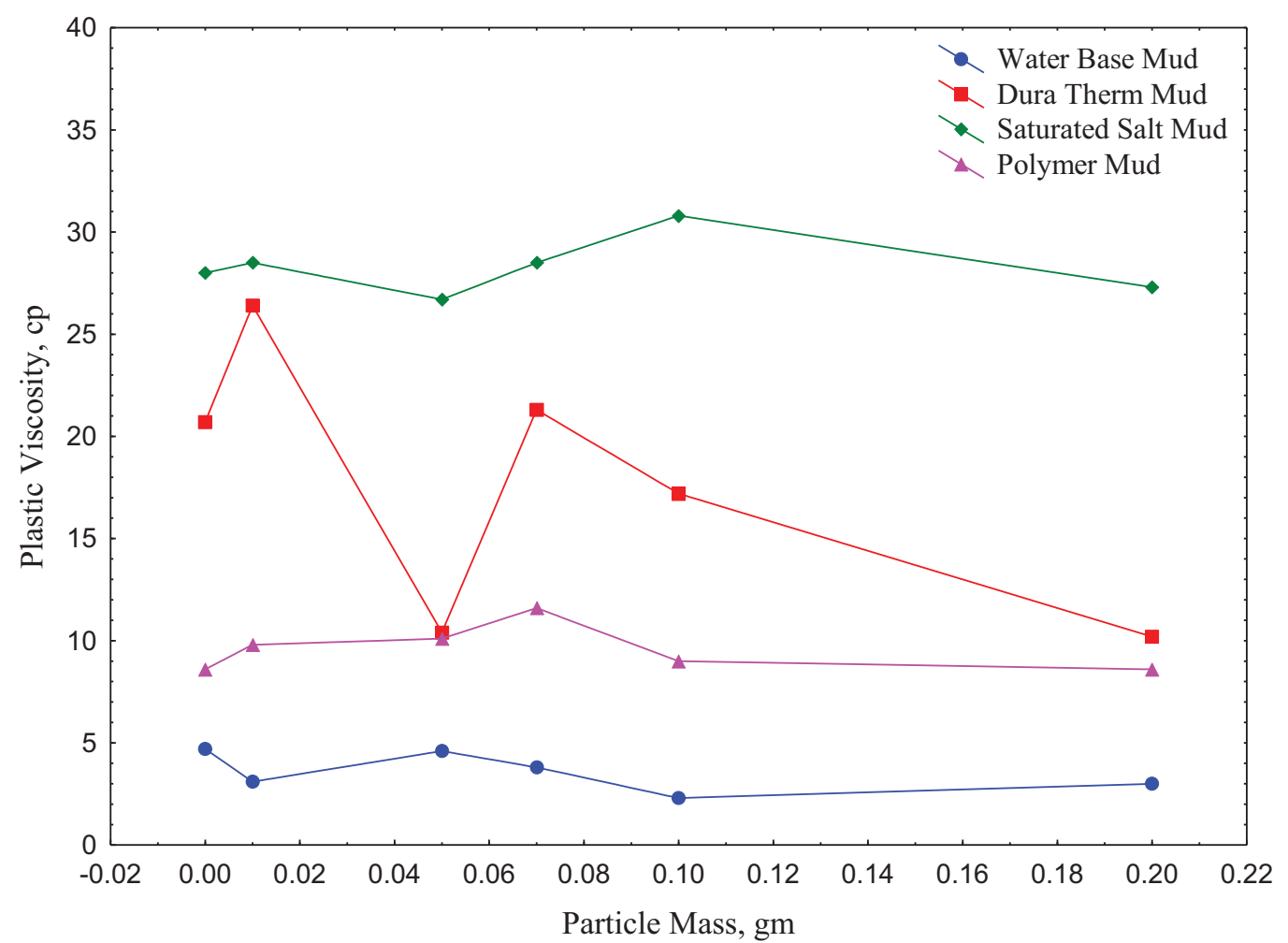

Fig. (10) The effect of MgO nanoparticle mass on plastic viscosity of different drilling fluid at $35^{\circ} \mathrm{C}$ and normal pressure 


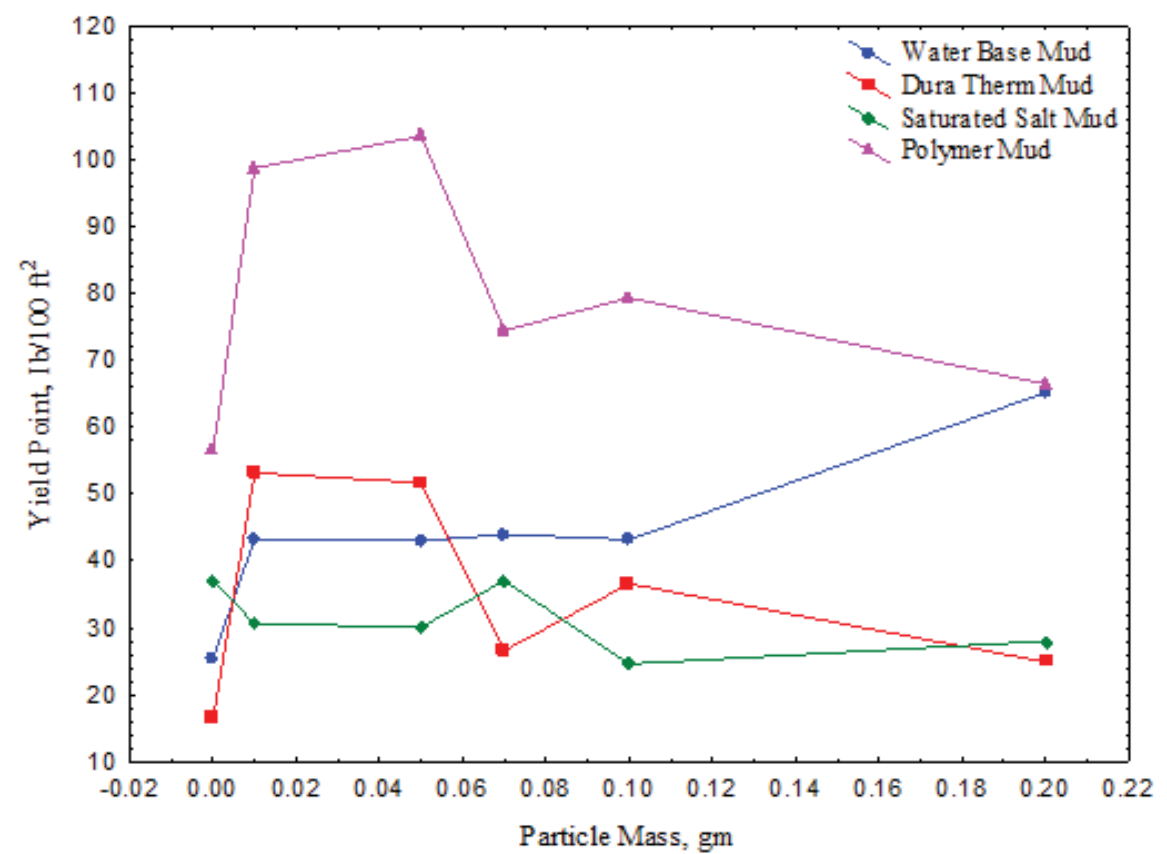

Fig. (11) The effect of MgO nanoparticle mass on yield point of different drilling fluidat $35^{\circ} \mathrm{C}$ and normal pressure

\section{Conclusion}

1. MgO NP at HPHT improves the results of filtration loss for DURA THERM mud (best at $0.07 \mathrm{gm}$ ), Salt Saturated Water mud (best at $0.2 \mathrm{gm}$ ) and slight improvement for polymer mud (best at $0.05 \mathrm{gm}$ ), while API WBM is not really affected by $\mathrm{MgO}$ nanoparticles.

2. The yield point as well as plastic viscosity can be improved with the addition of a specific value of $\mathrm{MgO}$ NP. 


\section{$\underline{\text { References }}$}

1. Tran X. Phuoc, Yee Soong, Minking K,Minking K. Chyu, Jung-Kun Lee "Nano particles application for controlling drilling fluid Rheological properties at High temperature"AADE 2009NTCE-11-05.

2. Max R.Annis and Martin V.Smith "Drilling Fluids Technology"1996. EXXON COMPANY, U.S.A.

3. Jim Friedheim, Steve Young, Guido De Stefano, John Lee and Quan Guo. "Nano technology for oil field application Hype or Reality?"2012."SPE paper 157032.

4. Abdul Razak Ismail, Tan Chee Seong, Nor Aziah Buang, Wan Rosli Wan Sulaiman" Improving Performance of Water-Drilling Fluids Using Nanoparticales " 2014.The 5th Sriwijaya International Seminar on Energy and Environment Science \& Technology.

5. Norazwan Wahld, Muhammed Aslam Md Yusof, Nor Hazimasture Hanafi "Optimum Nanosilica concentration in synthetic base mud for HTHP well"2015. SPE paper 176036.

6. Matthew M. Barry, Youngsoo Jung, Jung-Kun Lee, Tran X.Phuoc, Minking K. Chyu "Fluid filtration and rheological properties of Nanoparticle additive and intercalated clay hybrid bentonite drilling fluids"2015.Journal of Petroleum Science and Engineering, volume 127, pages 338-346.

7. Zisis Vryzas, Omer Mahmoud, Hisham A.Nasr-El-Din, Vassilios C.Kelessidis "Development and testing of novel drilling fluids using $\mathrm{Fe} 2 \mathrm{O} 3$ and siO2 nano particles for enhanced drilling operations"2015.IPTC-18381-MS.

8. Nada. S. Al-Zubaidi, Asawer. A. Alwasiti, Dena. Mahmood (2016). "A comparison of nano entonite and some nano chemical additives to improve drilling fluid using local clay and commercial bentonites". Egyptian of Petroleum Engineering.

9. Karagüzel, C., Çetinel, T., Boylu, F., Çinku, K., and Çelik, M.S." Activation of (Na, $\mathrm{Ca}$ )-bentonites with soda and $\mathrm{MgO}$ and their utilization as drilling mud", Applied Clay Science, 48 (2010) 398-404. 